\title{
THE PROSPECTS FOR ISLAMIC SOCIAL BANKING IN INDONESIA
}

\author{
M. Luthfi Hamidi ${ }^{1}$, Andrew C. Worthington ${ }^{2}$, Tracey West $^{3}$ and Rifki Ismal ${ }^{4}$ \\ ${ }^{1}$ Griffith University \& STEI SEBI, Australia \& Indonesia, mluthfi.hamidi@griffithuni.edu.au \\ ${ }^{2}$ Griffith University, Australia, a.worthington@griffith.edu.au \\ ${ }^{3}$ Griffith University, Australia, t.west@griffith.edu.au \\ ${ }^{4}$ Central Bank of Indonesia, Indonesia, rifki_ismal@yahoo.com
}

\begin{abstract}
Despite significant growth and development in recent years, Islamic banking (IB) continues to face widespread criticism due to its apparently weak social outcomes. This study investigates the social performance of Islamic banking in Indonesia, including its justification as an IB objective and the means of improvement. We surveyed 506 current and potential Islamic banking customers across six Indonesian provinces, combined with in-depth interviews with 10 Islamic banking experts consisting of regulators, practitioners, Sharia scholars, and academics. The findings strengthen previous results on the topic in that $42.89 \%$ of respondents consider that IB in Indonesia is socially defensive (doing the least that is required in terms of social outcomes), while $6.92 \%$ believe that it is reactive (doing less than that required). Of the remaining respondents, $34.78 \%$ consider the social performance as accommodative (doing all that is required) and $15.42 \%$ see it as proactive (doing more than is required). Most respondents $(52.96 \%$ ) suggest improvement by combining corporate social responsibility and the ZIS (Zakat, Infaq, shadaqah)-Waqf system. Only some (7.11\%) suggest the establishment of Islamic social banking, whose main feature would be to design an alternative to collateral so that low- and middle-income customers could more readily access bank financing. We recommend that regulators and practitioners take action to address these challenges through incentives and long-term strategic planning.
\end{abstract}

Keywords: Islamic Banking, Islamic Social Banking, Quadruple Bottom Line, Social Outcomes, ZIS-Waqf.

JEL Classification: A13; C83; D63; E58; G21; N30; Q51; Z12.

Article history:

Received : October 15, 2018

Revised : : May 02, 2019

Accepted : May 16, 2019

Available online : July 30, 2019

https://doi.org/10.21098/jimf.v5i2.1062 


\section{INTRODUCTION}

Although Islamic banking (IB) is theorized to be socially responsible (Asutay \& Harningtyas, 2015; Haniffa \& Hudaib, 2007), IB appears to have no particular concern when it comes to actual implementation. Some even suggest IB only has a trivial effect on disadvantaged people (Asutay, 2007, 2008; Mohd Nor, 2016), while others claim IB focuses on profit seeking as much as conventional banks (AbdulBaki \& Uthman, 2017; Abdul-Rahman, Latif, Muda, \& Abdullah, 2014).

In an attempt to enhance IB's social achievements, Dusuki (2008) suggest a corporate social responsibility (CSR) approach. In addition, the implementation of CSR would increase the response of IB in dealing with environment impacts, creating social benefits, and encouraging positive initiatives. As an alternative, Raimi, Patel, and Adelopo (2014) recommend combining CSR with the waqf (Islamic endowments) and zakat (Islamic compulsory charity) systems. Using two different simulation cases, Shahimi, Mohd Marzuki, and Embong (2013) argue that cash waqf contributes to alleviating poverty by up to $50 \%$ in Malaysia. More profoundly, however, other studies propose the establishment of Islamic social banking (ISB) as a response to the apparent failure of IB in delivering its purported social outcomes (Asutay, 2012; Mohd Nor, 2016). After conducting surveys and interviews with the stakeholders of Islamic banks in Malaysia, Mohd Nor, Rahim, and Senik (2016) suggest a social banking (SB) model could be incorporated in the day-to-day practices of Islamic banks and thereby enhance their social contribution.

Our study differs from previous research (Asutay, 2012; Dusuki, 2008; Mohd Nor et al., 2016; Raimi et al., 2014; Sairally, 2007) in a number of ways. First, this study could potentially be the first known attempt to consider the establishment of Islamic social banking in Indonesia. Second, while previous studies (Dusuki, 2005; Mohd Nor et al., 2016) employ only traditional survey methods using either handwriting surveys or emails, we used both a drop-off and online surveys, in conjunction with an initial pilot survey to improve accuracy of the final questionnaire. Third, also unlike existing work, our questionnaire uses a seven point Likert scale for the responses, as opposed to not five, which we believe not only more suited to electronic distribution (Finstad, 2010), but more reliable (Colman, Norris, \& Preston, 1997) and with more justifiable findings (Preston \& Colman, 2000). Such distinction should help guide future research in related areas. Fourth, unlike existing research that surveys only particular stakeholder groups, we included all of IB practitioners, regulators (Bank Indonesia, the Financial Services Authority, and the National Syari'ah Board) and academics. Such a method should yield better and more reliable findings. Last, unlike Mohd Nor et al. (2016) who recommend the internalization of social banking within an Islamic bank, we make the case for it as a separate and distinct business entity.

In Indonesia, the idea of establishing or internalizing SB principles in IB has thus far received little attention. However, this is perhaps only a matter of time, because the banking regulator has now newly committed itself to sustainable finance and sound banking, both socially and environmentally (OJK, 2015). To inform these developments, this paper investigates four primary questions. First, what is the social performance of IB in Indonesia? Second, should IB in Indonesia place a greater emphasis on the social dimension? Third, what is the preferred scenario to improve the social performance of Indonesian IB? Finally, what 
products and services would be preferred were ISB established in Indonesia? We conduct a survey, and further inform the results through interviews with IB experts.

This paper contributes to the literature at least in three ways. First, we provide an empirical assessment of the social outcomes of IB in Indonesia. Second, we discuss the options available to improve the social outcomes of IB. Third, we highlight the possible characteristics, services, and products of an ISB were it to be established. The structure of the paper is as follows: Section 2 provides a literature review, Section 3 the methodology, Section 4 the findings, Section 5 the conclusion, and Section 6 the recommendation.

\section{LITERATURE REVIEW}

\subsection{IB Social Objectives}

In relation to social objectives, Islamic scholars divide into two opposing groups on the role of social objectives in Islamic banking. A relative few believe that Islamic banks should be permitted to operate as normal business entities as long as their operations comply with Sharia (Lewis \& Algaoud, 2001; Satkunasegaran, 2003). In contrast, most Islamic scholars consider that Islamic banking should aim to support and encourage an economic system aimed at promoting a just, fair, and balanced society (Ahmad, 2000; Naqvi, 2016; Siddiqui, 2001). In doing so, any economic interaction in society is to "...increase the sum of public happiness, whilst reinforcing social solidarities and strengthening their values" (Tripp, 2006, p. 119). Similarly, (Al-Zuhayli, 2003, p. 250) stated “...the primary goal of Islamic financial institutions is not profit-making, but the endorsement of social goals of socio-economic development and the alleviation of poverty."

To implement such values, Islamic banks should include the important tenets of compliance in their daily activities, and place an emphasis not solely on financial profit, but also justice and societal obligation (Taqi-Usmani, 2002). Furthermore, Islamic banking is expected to be more socially responsible than conventional banks (Asutay \& Harningtyas, 2015; Haniffa \& Hudaib, 2007). As a result, Kamel (1997) argued that Islamic goals should include objectives relating to economic development, the creation of value-added, more exports and fewer imports, job creation, the rehabilitation of the incapacitated, and the training of others.

To date, this strong view of the social responsibility of Islamic bank has found legislative support in just a few countries, including Indonesia and Jordan (Hamidi \& Worthington, 2017). In evidence, the Republic of Indonesia Bylaws No. $21 / 2008$ on Islamic Banking Acts explicitly encourages Islamic banks to perform social functions. In comparison, Banking Law No. 28/ 2000 in Jordan requires that Islamic banks not only provide banking services, but help revive social solidarity and provide qardh al-hasan (benevolent loans) for the public interest.

\subsection{Actual Social Outcomes of IB}

According to Wood (1991) social outcomes comprise, for instance, social impact, programs, and policies aimed to recognize social concerns of stakeholders. In this regard, social outcomes can be described as a realization of IB's social objectives 
(Figure 1). For instance, alleviating poverty is part of social outcome, as the realization of disbursing zakat fund to support this goal illustrates the point.

Figure 1.

Social Objectives of IB and Its Realisation (Social Outcomes)

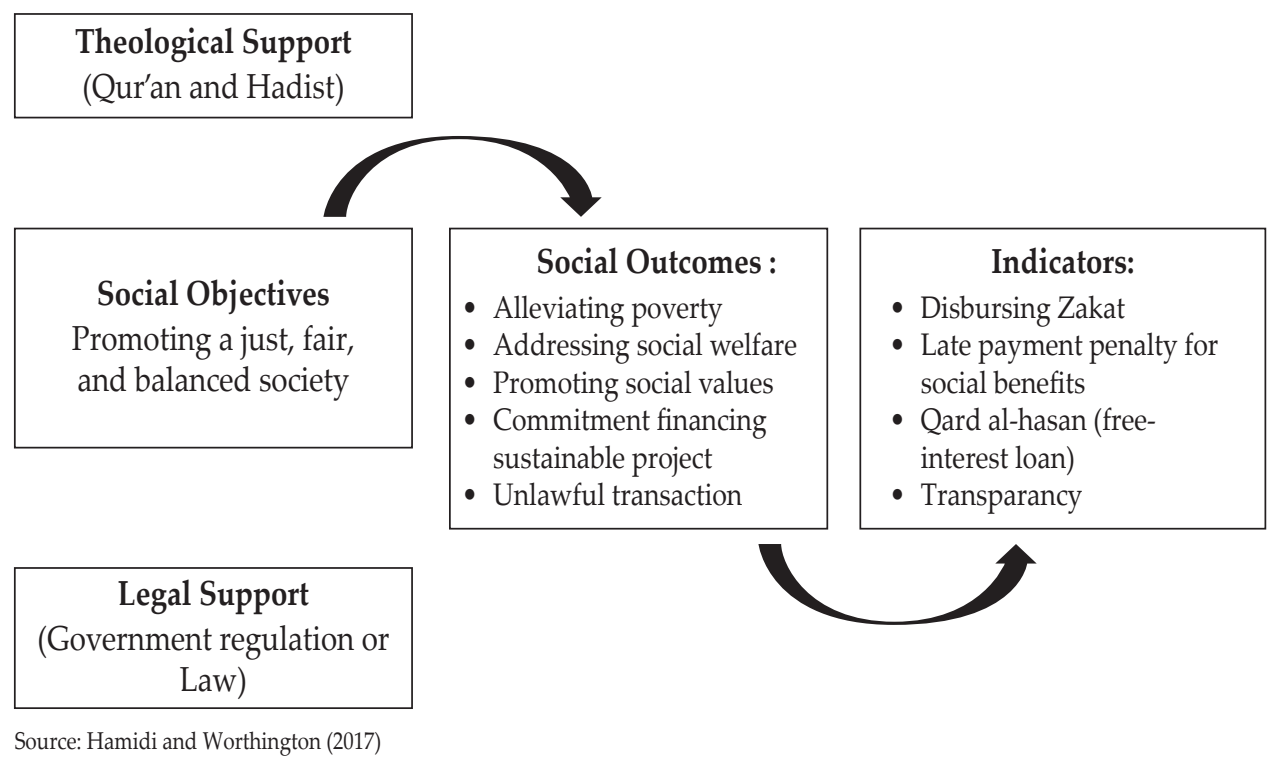

Scholars investigate IB's social outcomes from various perspectives such as CSR, ethical identity, and social reporting. Maali, Casson, and Napier (2006) employed a disclosure index method to assess 29 Islamic banks in 16 countries and reveal that social reporting is much less than that expected, with only those banks paying zakat demonstrating consistently good social disclosure. Elsewhere, Haniffa and Hudaib (2007) examined the ethical identity of seven Islamic banks and find that these failed to meet the ideal Islamic ethical identity in at least four dimensions: commitment to society, disclosure of corporate vision and mission, role in managing zakat, charity, and benevolent loans, and top management information. In other works, Kamla and G. Rammal (2013) used in-depth content analysis to investigate the social reporting (through annual reports and websites) of ten Islamic banks and reveal that these banks appear to commit little to helping eradicate poverty or strengthening social justice in society. Lastly, Mallin, Farag, and Ow-Yong (2014) employed samples of 90 Islamic banks across 13 countries, finding that the banks paid rather less attention to the environment than expected, while Amran et al. (2017) compared the CSR of Islamic banks in Indonesia and Malaysia and show progress in both countries, mostly to do with the workplace and community. 


\subsection{From SB to ISB}

While most banks keep their commitment to social dimensions through a consistently applied corporate social responsibility model, other banks emphasize their strategies on social achievement. These banks are well known as social banking (SB). Guene and Mayo (2001, p. 1) defined "Social banking as where the supplier of financial services take a positive interest in the social outcomes and effects of their activities". Alternatively, Cornée and Szafarz (2014, p. 361) simply contended that SB is "financial intermediaries paying attention to noneconomic (i.e., social, ethical, and environmental) criteria". Some researchers use the term "green banking" (Biswas, 2016; Kaur, 2016), "ethical bank" (Chew, Tan, \& Hamid, 2016; Paulet, Parnaudeau, \& Relano, 2015; San-Jose, Retolaza, \& Gutierrez-Goiria, 2011), a "sustainable bank" (Korslund \& Spengler, 2012), or an "alternative bank" (Butzbach \& von Mettenheim, 2015).

No matter how varied the name seems, yet essentially, it comprises triple bottom line principles. Such principles were introduced by Elkington (1997) in his seminal book Cannibals with Forks: The Triple Bottom Line of 21st Century Business, in which he suggested businesses should not only include economic, but also social and environmental factors to assess its performance. The parameters later on became popular as triple bottom line (TBL) principles and were sometimes described using other terms, such as profit, people and planet (3Ps) (Slaper \& Hall, 2011; Vanclay, 2010). In banking industry, the 3Ps as can be seen from the Figure 1, Panel (a) are adopted as the principle of social banking (Benedikter, 2011; Cornée \& Szafarz, 2014; De Clerck, 2009; San-Jose et al., 2011; Weber, 2014). Hamidi and Worthington (2017) stated that in fact all these criterions appear in IB, with different emphasis. For instance, IB considers both financial and social outcomes are equally important, although in reality financial matters prevail (Hassan \& Bashir, 2003). Unlike conventional banks, IB has unique services such as zakat and qard al-hasan, with both schemes having the potential to empower the poor. Hence, IB is a parallel to "people". In regards to environment, many verses in the Qur'an, the Holy Scripture for Muslim, explicitly advocate people to keep and preserve their nature although in reality it seems to be ignored in favor for profitability (Hamidi \& Worthington, 2018). The addition P for "Prophet" as suggested by (Hamidi \& Worthington, 2017, 2018) refers to the central role of the Prophet as God's messenger in account that all his thoughts can be applied as an ethical guidance for IB. The 4Ps, later titled the quadruple bottom line (QBL), are just one proposed framework for establishing ISB (Figure 2, Panel b). 
Figure 2.

From Triple Bottom Line (3P) to Quadruple Bottom Line (4P)

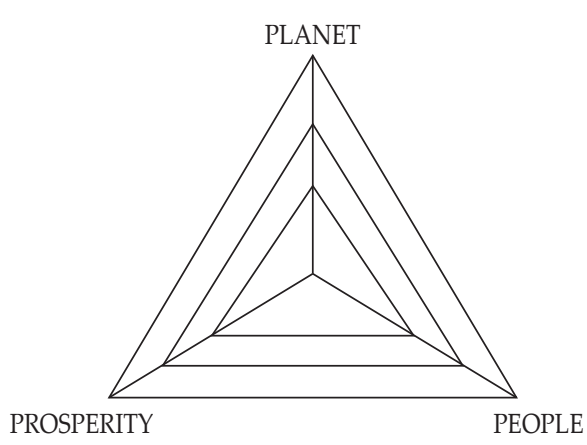

(a)

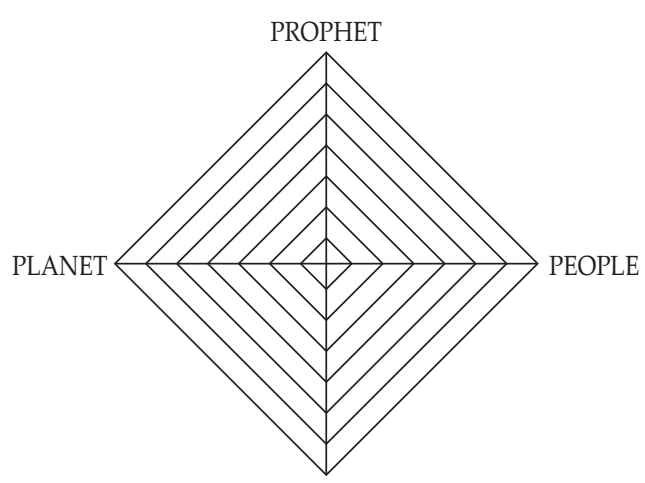

PROSPERITY

(b)

Source: Hamidi and Worthington (2018)

Table 1 shows the central differences in term of business model, product and services, and credit policy between SB, IB, and ISB. Some SB practices may be internalized within ISB, such as exposing transparency, e.g., customers may know where fund collected are distributed and designing flexible collateral, e.g., an alternative system to provide productive access to credit. Furthermore, encouraging the financing of social, ethical, and environmental projects is a priority (Hamidi \& Worthington, 2018).

Table 1.

Comparison among SBs, IBs, and ISB

\begin{tabular}{|c|c|c|c|}
\hline SBs & IBs (de jure) & IBs (de facto) & ISB \\
\hline \multicolumn{4}{|l|}{ Business model } \\
\hline $\begin{array}{l}\text { Profit-making, but } \\
\text { parallel optimization of } \\
\text { social added value }\end{array}$ & $\begin{array}{l}\text { Mixed, financially and } \\
\text { socially acceptable }\end{array}$ & $\begin{array}{l}\text { Tend to focus on profit- } \\
\text { making rather than } \\
\text { social motive, with } \\
\text { exception on zakat and } \\
\text { qard al- hasan channels }\end{array}$ & $\begin{array}{l}\text { Mixed, financially and } \\
\text { socially acceptable, } \\
\text { with emphasising on } \\
\text { waqf-zakat-qard al-hasan } \\
\text { system }\end{array}$ \\
\hline \multicolumn{4}{|l|}{ Products and services } \\
\hline $\begin{array}{l}\text { Focus on banking basics: } \\
\text { Saving collection and } \\
\text { credit distribution }\end{array}$ & $\begin{array}{l}\text { Focus on common } \\
\text { banking service, with } \\
\text { special attention on } \\
\text { profit-loss sharing } \\
\text { projects }\end{array}$ & $\begin{array}{c}\text { Mostly replicating } \\
\text { conventional bank } \\
\text { financial engineering } \\
\text { tools. Profit-loss sharing } \\
\text { in many cases are trivial }\end{array}$ & $\begin{array}{l}\text { Focus on common } \\
\text { banking service, with } \\
\text { special attention on } \\
\text { profit-loss sharing } \\
\text { projects }\end{array}$ \\
\hline \multicolumn{4}{|l|}{ Credit policy } \\
\hline $\begin{array}{l}\text { Based on triple } \\
\text { bottom line analysis } \\
\text { (environmental, social } \\
\text { and financial) }\end{array}$ & $\begin{array}{c}\text { Islamic ethics system } \\
\text { encourages IB to adopt } \\
\text { triple bottom line } \\
\text { analysis }\end{array}$ & $\begin{array}{l}\text { Financial outcome } \\
\text { (single bottom line) } \\
\text { mostly adopted as } \\
\text { measurement. }\end{array}$ & $\begin{array}{l}\text { Adopting quadruple } \\
\text { bottom line principle } \\
\text { (prosperity, people, } \\
\text { planet, and prophet) }\end{array}$ \\
\hline
\end{tabular}

Source: Hamidi and Worthington (2018) extended. 


\section{METHODOLOGY}

Researchers have employed various paradigms according to the nature of their research. To begin with, Kuhn (1996) defined a paradigm as "the set of common beliefs and agreements shared between scientists about how problems should be understood and addressed". There are different competing paradigms such as: positivist/post-positivist, interpretive-constructive, critical, pragmatic worldview, and postmodern/post structural (Creswell, 2009; Denzin \& Lincoln, 2018; Tracy, 2012). Therefore, the fittest paradigm to be applied for the research needs to be discovered. On the other hand, positivist researchers believe that the truth about something they observe already exists and only needs their investigation to find it (Tracy, 2012). In contrast, interpretivist (or constructivist) scholars suggest that reality is not something easily explained in a statement. Instead, the creation of knowledge is constructed and produced through intense interaction and practices facilitated by the inquirer (Tracy, 2012). Both positivist and interpretivist paradigms have their strengths and weaknesses, which at first glance seem irreconcilable (Lin, 1998). Instead of using one of these paradigms, Roth and Mehta (2002) suggested combining the two approaches because by using the combination a better understanding may be generated.

We will employ two paradigms simultaneously in order to obtain a deeper understanding and better results. We intend to apply a pragmatic paradigm to address the research for several reasons. First, pragmatism is associated with mixed methods research, providing the researcher with a flexibility to use all suitable methods (Creswell, 2009). Second, this combination of approaches tend to provide deeper understanding and more generalizable findings (Neuman, 2014). Third, it enhances and strengthens research results (Amaratunga, Baldry, Sarshar, \& Newton, 2002). Fourth, we can minimize the disadvantages that may occur, because the strengths of one method offset the weaknesses of the other. Following this, we employ a sequential explanatory design, as shown in Table 2. Phase 1 employs a quantitative approach through conducting a survey to capture the perceptions of IB stakeholders in terms social outcomes, while Phase 2 uses a quantitative approach to scrutinize some relevant ideas about the social dimension of IB and the idea of establishing ISB.

Table 2.

Sequential Explanatory Design of the Research

\begin{tabular}{|c|c|}
\hline Phases & Description/source \\
\hline \multicolumn{2}{|l|}{ Phase 1: Quantitative Approach } \\
\hline $\begin{array}{l}\text { - Conducting a survey for Islamic banking in } \\
\text { term of social outcomes }\end{array}$ & $\begin{array}{l}\text { - Drop-off survey in } 5 \text { provinces } \\
\text { - Online survey }\end{array}$ \\
\hline \multicolumn{2}{|l|}{ Phase 2: Qualitative approach } \\
\hline $\begin{array}{l}\text { - Conducting in-depth interview } \\
\text { - Exploring the idea of Islamic social banking }\end{array}$ & $\begin{array}{l}\text { - } \text { Purposive sampling } \\
\text { - In-depth interview } \\
\text { - Experts from many backgrounds } \\
\text { - } \text { Regulators (BI, OJK, DSN) } \\
\text { - Practitioners } \\
\text { - Academics }\end{array}$ \\
\hline
\end{tabular}




\subsection{Data Collection and Analysis}

The data was collected through a drop-off survey (a questionnaire send to respondents so that they were able to complete the questionnaire at workplace or home) and an Internet survey. Unfortunately, as the survey design was for a self-administered questionnaire, there was no opportunity for the research team to explain or clarify questions from the respondents. To overcome this problem, we distributed an online pilot test from 21 November-29 December 2017. This experimental survey participated by 137 respondents was to ensure that the respondents easily understood all questions. Based on this pilot test, a new questionnaire was developed and distributed in five provinces in Indonesia, i.e., DKI Jakarta, Banten, West Java, Central Java, and DI Yogyakarta. Out of 420 sets of questionnaire distributed, as many as 274 were completed, resulting in a $65 \%$ response rate. All five provinces were well represented in terms of the conduct of Islamic banking in Indonesia, as they account for $46 \%$ of offices and $65.25 \%$ of businesses and customers. The number of respondents for each province is shown in Table 3. As far as the online survey from 1 February-1 March 2018 is concerned, 245 respondents participated, which in total yielded 519 responses. However, only 506 were usable for the analysis. Non-probability convenience sampling, commonly used in banking research was implemented (Kumar, Tat Kee, \& Taap Manshor, 2009; Pikkarainen, Pikkarainen, Karjaluoto, \& Pahnila, 2006; Poon, 2007).

The questionnaire survey draws on previous studies in the area of IB (Dusuki, 2005; Gait \& Worthington, 2015; Mohd Nor et al., 2016; Zakaria, 2014). The questionnaire comprises close-ended questions using multiple-choice questions and responses on a seven-point Likert scale. The questionnaire investigates three main investigations: (1) the characteristics of respondent demographic profiles, i.e., gender, age, province, religion, education, occupation, and income, (2) perceptions of current IB social outcomes and any possible improvements, and (3) the characteristics of ISB, including preferred products and services, if applicable. Data were analyzed descriptively and evaluated within the Kruskal-Wallis framework, which is to identify whether independent samples have identical distribution or they have differences between groups (Schlotzhauer, 2007).

In addition to the survey, we also analyzed verbal and personal interactions based on face-to-face interviews to obtain more detailed information from the respondents. Data were transcribed and coded into various themes. We used NVivo 12 to generate patterns and visualize data into meaningful tables and graphs.

\subsection{Sampling}

Table-3 provides the descriptive statistics of respondents. More males $(59.9 \%$ or 303 participants) than females ( $40.1 \%$ or 203 people) participated in the survey. $39.7 \%$ participants were between $26-35$ years, while $25.1 \% 36-45$ years old. $19 \%$ were $18-25$ years old, $13.6 \% 46-55$ years old, and $2.6 \%$ more than 55 years old.

Most respondents lived in West Java (34.2\%), followed by DKI Jakarta (19\%), DI Yogyakarta (17\%), Central Java (12.5\%), Outside Java (8.5\%), Banten (4.5\%), and East Java (4.3\%). Most respondents from Yogyakarta, Central Java, and Banten, which encapsulated almost one-third of the population, were associated with Islamic Rural Banks catering for small and medium enterprises. 
As expected, nearly all (99\%) respondents were Muslims, while the rest Catholics $(0.6 \%)$ and Protestants $(0.4 \%)$. In terms of education, most were relatively well educated, with 44 participants (8.7\%) holding a college diploma, 299 (59.1\%) a bachelor degree, $96(19 \%)$ a master's degree, and $16(3.2 \%)$ a doctoral degree. Only 47 participants $(9.3 \%)$ had primary or secondary education.

As far as occupational status is concerned, 40.7\% respondents were employees (others), while $15.6 \%$ managers/executives, $10.5 \%$ professionals, $8.3 \%$ academics, $7.9 \%$ merchants'/business owners, $7.5 \%$ government employees, $6.1 \%$ students, $2.8 \%$ housewives, $0.4 \%$ farmers, and $0.2 \%$ unemployed. The majority of respondents were of lower income level, with monthly income ranging from less than IDR 2,000,000 (13.2\%) and between IDR 2,000,001 (40.9\%) and IDR 5,000,000, while $21.9 \%$ participants were of the middle income level, and $12.8 \%$ upper middle income. The remaining $11.1 \%$ of respondents were of high income level.

In terms of Islamic banking, most respondents (72.3\%) had an account in both Islamic and conventional banks, while the remainder $(36.8 \%)$ was customers only of Islamic banks. The primary relations were as depositor $(36.8 \%)$ or depositor and practitioner $(31.6 \%)$, followed by depositor and borrower $(17.6 \%)$, depositor and academic (3\%), depositor and regulator $(1.8 \%)$, depositor and Sharia adviser $(0.6 \%)$, depositor and stockholder $(0.4 \%)$, and general community $(8.3 \%)$.

Table 3.

Profile of Respondents

\begin{tabular}{lccc}
\hline Characteristics & & $\mathbf{N}$ & $\mathbf{\%}$ \\
\hline Gender & Male & 303 & 59.9 \\
Age & Female & 203 & 40.1 \\
& $18-25$ & 96 & 19.0 \\
& $26-35$ & 201 & 39,7 \\
& $36-45$ & 127 & 25.1 \\
Province & $46-55$ & 69 & 13.6 \\
& Above 55 & 13 & 2.6 \\
& DKI & 96 & 19.0 \\
& West Java & 173 & 34.2 \\
& Banten & 23 & 4.5 \\
& Central Java & 63 & 12.5 \\
Religion & DIY & 86 & 17.0 \\
& East Java & 22 & 4.3 \\
& Outside Java & 43 & 8.5 \\
Education & Islam & 501 & 99.0 \\
& Catholic & 3 & 0.6 \\
& Christian & 2 & 0.4 \\
& Primary/Secondary School & 47 & 9.3 \\
& College Diploma & 44 & 8.7 \\
& Bachelor Degree & 299 & 59.1 \\
& Master Degree & 96 & 19.0 \\
& Doctoral Degree & 16 & 3.2 \\
& Other & 4 & 0.8 \\
\hline
\end{tabular}


Table 3.

Profile of Respondents (Continued)

\begin{tabular}{lccc}
\hline Characteristics & $\mathbf{N}$ & $\mathbf{\%}$ \\
\hline Occupation & Manager/Executive & 79 & 15.6 \\
& Professional (Lawyer, Accountant, Doctor etc.) & 53 & 10.5 \\
& Academics & 42 & 8.3 \\
Merchant/Business owner & 40 & 7.9 \\
Government employee & 38 & 7.5 \\
& Farmer & 2 & 0.4 \\
Income & House wife & 14 & 2.8 \\
& Student & 31 & 6.1 \\
& Unemployed & 1 & 0.2 \\
Other (employees) & 206 & 40.7 \\
Bank Account & 67 & 13.2 \\
& Below IDR 2,000,000.00 & 207 & 40.9 \\
Role & IDR 2,000,001.00 - IDR 5,000,000.00 & 111 & 21.9 \\
IDR 5,000,001.00 - IDR 10,000,000.00 & 65 & 12.8 \\
IDR 10,000,001.00 - IDR 20,000,000.00 & 56 & 11.1 \\
More than IDR 20,000,001.00 & 366 & 72.3 \\
& Islamic and conventional bank & 140 & 27.7 \\
Islamic only & 186 & 36.8 \\
& Depositor only & 89 & 17.6 \\
& Depositor \& borrower & 160 & 31.6 \\
& Depositor \& practitioner & 3 & 0.6 \\
& Depositor \& Syariah adviser & 9 & 1.8 \\
Depositor \& regulator & 15 & 3.0 \\
Depositor \& Academia & 2 & 0.4 \\
& Depositor \& Stockholder & 42 & 8.3 \\
\hline
\end{tabular}

The participant interviews were obtained from the population through multistage or clustering procedures. As such, we first identified clusters, e.g., related organizations or institutions. We then searched for the individual names within the clusters. Last, we sampled the targeted names (Creswell, 2009). Samples were collected using purposive sampling, aiming at targeting relevant interviewees to answer the research questions (Bryman, 2016) . The interviewees came from various backgrounds, including a regulatory body, such as Bank Indonesia, OJK, DSN, practitioners, and academics. Table 4 lists the respondents. 
Table 4.

List of Interviewees, their Institutions and Positions

\begin{tabular}{llcc}
\hline No & \multicolumn{1}{c}{ Institution } & Respondent Code & Positions \\
\hline 1 & Regulator & R1 & Senior Researcher \\
2 & Regulator & R2 & Director \\
3 & Islamic commercial bank & R3 & President Director \\
4 & Regulator & $\mathrm{R} 4$ & Deputy Director \\
5 & Regulator & $\mathrm{R} 5$ & Syariah Advisor \\
6 & University & $\mathrm{R} 6$ & Senior Lecturer \\
7 & Islamic commercial bank & $\mathrm{R} 7$ & Commissioner \\
8 & Islamic Rural Bank & $\mathrm{R} 8$ & President Director \\
9 & Islamic commercial bank & $\mathrm{R} 9$ & Syariah Advisor \\
10 & Islamic Business Unit & $\mathrm{R} 10$ & Director \\
\hline
\end{tabular}

\section{RESULTS AND DISCUSSION}

\subsection{Responses on Delivering Social Outcomes}

As discussed, scholars have had different opinions on the way IB responds to social outcomes. On the one hand, they tend to liberate IB to be a normal business entity for pursuing profit. To illustrate, IB shall not use a considered amount of shareholder's fund to be used for social activities, because it might jeopardize the bank (Lewis \& Algaoud, 2001; Satkunasegaran, 2003). On the other hand, many have suggested IB to deliver social outcomes, because this issue is inseparable and important for IB as its focus is on pursuing profit.

From the survey, respondents seemed to go with the second opinion (Table 5). Most respondents (48.2\%) agreed and (24.5\%) strongly agreed suggesting IB shall actively take part on social activities, because this is an essential part of its philosophical foundation. The majority of respondents (46.4 agree and 34.6 strongly agree) believe by conducting their social agenda will strengthen the status of the bank. Another interesting point, the majority of participants $(45.3 \%$ in strongly agreement and $36.8 \%$ agreement) seem to insist that IB had a better social result than conventional banks.

Table 5.

IB Stakeholders' Perception on Delivering Social Outcomes

\begin{tabular}{|c|c|c|c|c|c|c|c|c|}
\hline Items & 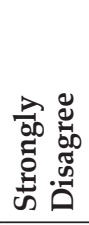 & 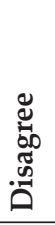 & 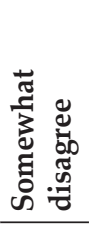 & 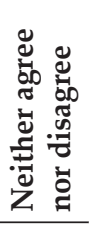 & & 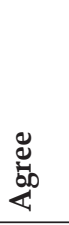 & 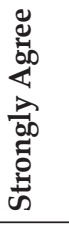 & 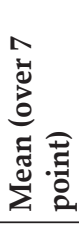 \\
\hline $\begin{array}{l}\text { Islamic banks should not abandon } \\
\text { delivering social outcomes because it is a } \\
\text { part of its founding philosophy }\end{array}$ & 1.2 & 3.4 & 3.8 & 14 & 4.9 & 48.2 & 24.5 & 5.61 \\
\hline $\begin{array}{l}\text { Doing social outcomes will strengthen } \\
\text { reputation of Islamic Banks }\end{array}$ & 0.8 & 0.8 & 1.2 & 7.9 & 8.3 & 46.4 & 34.6 & 6.00 \\
\hline $\begin{array}{l}\text { Islamic banks should show higher social } \\
\text { results than conventional banks }\end{array}$ & 0.4 & 0.2 & 1.4 & 9.7 & 6.3 & 36.8 & 45.3 & 6.13 \\
\hline
\end{tabular}


Further explanation from the Kruskal-Wallis test (Table 6) suggests that all three questions statistically insignificant (Asymp. Sig. > 0.05) indicates that there are no differences in perception among the different stakeholders' role. In other words, almost all of respondents have voiced the similar opinion on the essence of delivering social outcomes for IB. They expect IB will do such a task better than the conventional bank. Yet, from the perspective of interviewees, they differ in defining what social aspects of IB are included. Some of these following statements illustrate the point.

"Social finance includes ziswaf [zakat, infaq, sedekah, waqf) in which the institution has a capacity as amil (collector of zakat) as well as nazhir (managing of waqf)." R1

"The so-called social is more to allowing deprive people to have equal opportunity to restore in many ways, for instance financing to help infrastructure. The IB's commercial goal is at around $90 \%$, while the remaining is for social purpose." R2

"Social function in the form of baitul mal institution, receiving funds from zakatwaqf, grants, or other social funds, and channeling them to zakat management organizations." R4

"The social part of the bank is when we can create opportunities. Why are we using opportunity? That opportunity, if I say the opportunity, we talk about lead the middle class, we got a lot in Indonesia. However, when we talk about low segment, they do not have a chance. We take that way women as our priority. First, we select productive poor women then we provide training. This is very important; empowerment is very important." R7

Table 6.

Kruskal-Wallis tests: Respondents' Responses on IB's Social Outcomes

\begin{tabular}{|c|c|c|c|c|}
\hline Questions & Role & $\mathbf{N}$ & $\begin{array}{l}\text { Mean } \\
\text { Rank }\end{array}$ & $\begin{array}{l}\text { Asymp. } \\
\text { sig. (p) }\end{array}$ \\
\hline \multirow{9}{*}{$\begin{array}{l}\text { Islamic banks should not abandon } \\
\text { delivering social outcomes because it is } \\
\text { a part of its founding philosophy }\end{array}$} & Depositor only & 186 & 251.54 & .494 \\
\hline & Depositor as well as a borrower & 89 & 239.65 & \\
\hline & $\begin{array}{l}\text { Depositor as well as practitioner } \\
\text { (manager and staff) }\end{array}$ & 160 & 262.08 & \\
\hline & $\begin{array}{c}\text { Depositor as well as a Syariah } \\
\text { adviser } \\
\end{array}$ & 3 & 322.33 & \\
\hline & Depositor as well as a regulator & 9 & 260.67 & \\
\hline & Depositor as well as an academic & 15 & 312.97 & \\
\hline & $\begin{array}{l}\text { Depositor as well as an owner } \\
\text { (stock holder) }\end{array}$ & 2 & 261.25 & \\
\hline & Community (none above) & 42 & 230.80 & \\
\hline & Total & 506 & & \\
\hline \multirow{9}{*}{$\begin{array}{l}\text { Doing social outcomes will strengthen } \\
\text { reputation of Islamic Banks }\end{array}$} & Depositor only & 186 & 247.84 & .602 \\
\hline & Depositor as well as a borrower & 89 & 243.39 & \\
\hline & $\begin{array}{l}\text { Depositor as well as practitioner } \\
\text { (manager and staff) }\end{array}$ & 160 & 264.02 & \\
\hline & $\begin{array}{c}\text { Depositor as well as a Syariah } \\
\text { adviser }\end{array}$ & 3 & 144.33 & \\
\hline & Depositor as well as a regulator & 9 & 289.72 & \\
\hline & Depositor as well as an academic & 15 & 286.77 & \\
\hline & $\begin{array}{l}\text { Depositor as well as an owner } \\
\text { (stock holder) }\end{array}$ & 2 & 215.25 & \\
\hline & Community (none above) & 42 & 249.92 & \\
\hline & Total & 506 & & \\
\hline
\end{tabular}


Table 6.

Kruskal-Wallis tests: Respondents' Responses on IB's Social Outcomes (Continued)

\begin{tabular}{|c|c|c|c|c|}
\hline Questions & Role & $\mathbf{N}$ & $\begin{array}{l}\text { Mean } \\
\text { Rank }\end{array}$ & $\begin{array}{l}\text { Asymp. } \\
\text { sig. (p) }\end{array}$ \\
\hline \multirow{9}{*}{$\begin{array}{l}\text { Islamic banks should show higher } \\
\text { social results than conventional banks }\end{array}$} & Depositor only & 186 & 250.68 & .322 \\
\hline & Depositor as well as a borrower & 89 & 231.13 & \\
\hline & $\begin{array}{c}\text { Depositor as well as practitioner } \\
\text { (manager and staff) }\end{array}$ & 160 & 266.63 & \\
\hline & $\begin{array}{c}\text { Depositor as well as a Syariah } \\
\text { adviser }\end{array}$ & 3 & 203.83 & \\
\hline & Depositor as well as a regulator & 9 & 287.67 & \\
\hline & Depositor as well as an academic & 15 & 309.00 & \\
\hline & $\begin{array}{l}\text { Depositor as well as an owner } \\
\text { (stock holder) }\end{array}$ & 2 & 199.50 & \\
\hline & Community (none above) & 42 & 242.36 & \\
\hline & Total & 506 & & \\
\hline
\end{tabular}

\subsection{Responses on IB's Social Responsiveness}

The term social responsiveness is measured by using a four-category rating: reactive, defensive, accommodative, and proactive (RDAP Scale). This scale was introduced by Carroll (1979), Wartick and Cochran (1985), Clarkson (1995), and further modified by (Hamidi \& Worthington, 2018) as shown in Table 7.

Table 7.

RDAP Scale for Assessing Social Responsiveness

\begin{tabular}{llll}
\hline Achievement (\%) & \multicolumn{1}{c}{ Rating } & \multicolumn{1}{c}{ Posture or Strategy } & \multicolumn{1}{c}{ Performance } \\
\hline $0-40$ & Reactive & Deny responsibility & Doing less than required \\
$41-50$ & Defensive & Admit responsibility but fight it & Doing the least that is required \\
$51-60$ & Accommodative & Accept responsibility & Doing all that is required \\
$61-100$ & Proactive & Anticipate responsibility & Doing more than is required \\
\hline
\end{tabular}

When requested to respond about the social responsiveness of IB, the majority respondents of survey (42.89\%) state that IB is in defensive level (doing the least that is required), while few of them $(6.92 \%)$ suggest even worst that IB is reactive point (doing less than required). On the contrary, $34.78 \%$ of respondents believe that IB is in the accommodative position (doing all that is required) and further $15.42 \%$ of them state that IB is proactive (doing more than is required) in delivering social outcomes (Graph 1). 


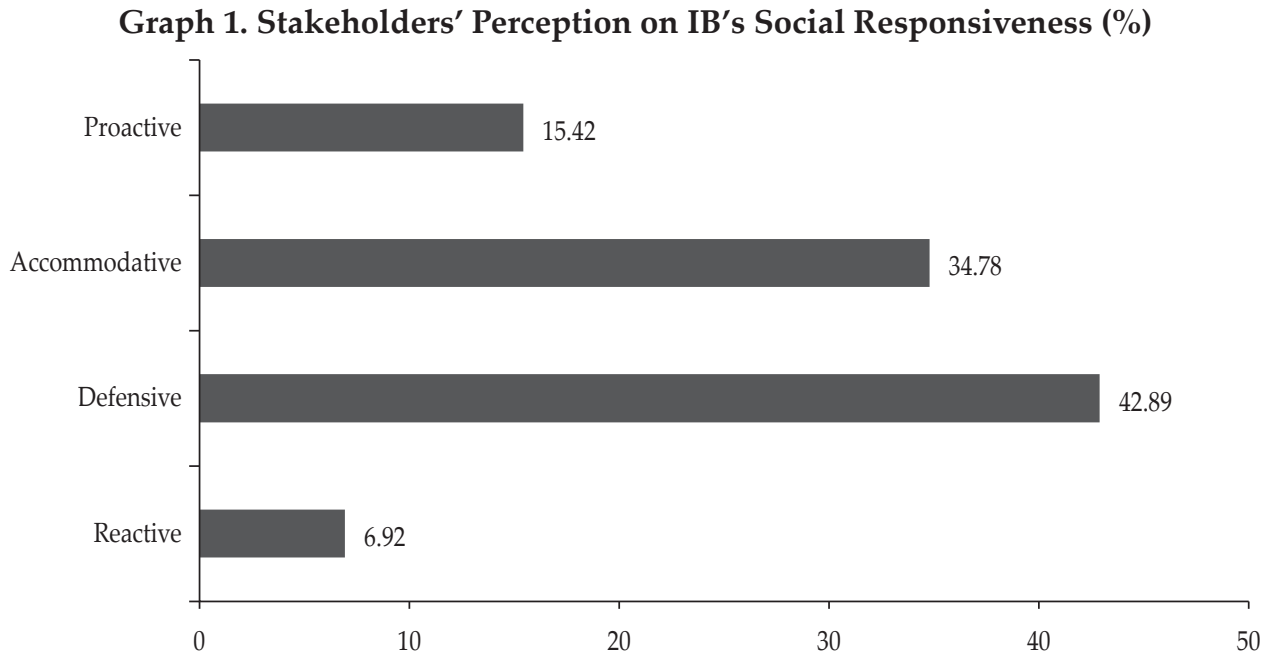

If we search into detail in the educational segment, those pinpointing that IB is currently in defensive level are supported by participants from more educated respondents $(7$ doctorates, 40 master's degree holders, 130 bachelor degree holders, 19 college diploma holders, and 20 primary school graduates), while the supporters of accommodative level is fewer ( 3 doctorates, 36 master's degree holders, 107 bachelor degree holders, 14, college diploma holders, and 15 primary/ secondary school graduates) (Graph 2).

\section{Graph 2.}

Stakeholders' Perception on Social Outcomes of IB Based on Their Education

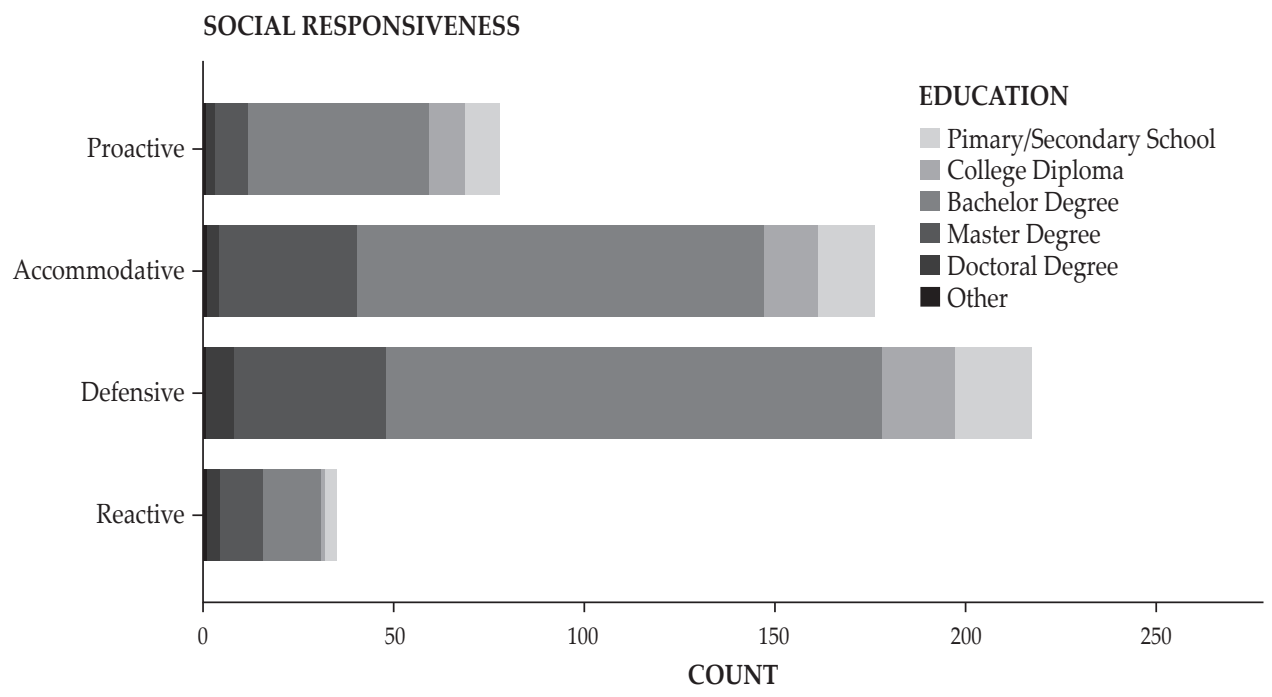


Once we confronted the experts with the results, almost all of them concurred. Seven out 10 interviewees responded: five professionals suggested the social outcomes of IB were less than expectations, none considers as expected, and two were neutral (no positive or negative assessment) as can be depicted in Table 8 .

Table 8.

Experts' Responses on IB's Social Responsiveness

\begin{tabular}{lcccc}
\hline & \multicolumn{4}{c}{ Responses } \\
\cline { 2 - 4 } Interviewees & As expected & Neutral & $\begin{array}{c}\text { Under } \\
\text { expectation }\end{array}$ & Total \\
\hline R1 & 0 & 0 & 1 & 1 \\
R2 & 0 & 0 & 1 & 1 \\
R3 & 0 & 1 & 0 & 1 \\
R4 & 0 & 0 & 0 & 0 \\
R5 & 0 & 0 & 1 & 1 \\
R6 & 0 & 0 & 0 & 0 \\
R7 & 0 & 0 & 0 & 0 \\
R8 & 0 & 0 & 1 & 1 \\
R9 & 0 & 0 & 1 & 1 \\
R10 & 0 & 1 & 0 & 1 \\
\hline Total (10) & 0 & 2 & 5 & 7 \\
\hline Note: 0 indicates disagree with statement, 1 otherwise & & &
\end{tabular}

The respondents who agreed that social outcomes of IB are at low level, suggest an immediate improvement need to be done. Some illustrative comments are as follow:

"Yes, it is still far, because they only depend on management, it means depending on the owner. If the owner does not care, there will be none [social activities]." R1

"It is still far. No money no action. It can be said that Islamic banking today is still marginal. In this sense, I have to say that the level of efficiency compared to conventional is still lower, why? Because some things are actually sunatullah [Law of God]. The sunnatullah suggests the power of number. The larger the assets, the more efficient." R2

"We have social activities, but only in the form of CSR. However, the number is small, only a few billion rupiahs. Small. If we want it to be larger, the question is: we have to set up the infrastructure, don't we?" R10

\subsection{Some Approaches to Improve IB's Social Responsiveness}

While graph 1 demonstrates that almost a half of the respondents (total of defensive $42.89 \%$ and reactive $6.92 \%$ ), it indicates that the social outcomes resulted from IB is not impressive suggesting that there is a need to improve it. There are possible approaches to improve as suggested by the scholars including: (1) maximizing CSR (Dusuki, 2005), (2) combining CSR with waqf and zakat system (Raimi et al., 2014), (3) establishing Waqf bank (Mohammad, 2011), (4) establishing ISB trough 
micro finance or Bait al Maal wat Tamwil or BMT (Hamidi \& Worthington, 2017), (5) establishing an ISB as new business entity. Among these options, the majority of respondents (52.96) prefer scenario number 2, followed by emphasizing CSR (25.1\%) and BMT (9.09). Only a small number (7.11\%) considered the idea of ISB is ready (Graph 3).

Graph 3.

Stakeholders' Perception on How to Improve Social Outcomes of Islamic Banks (\%)

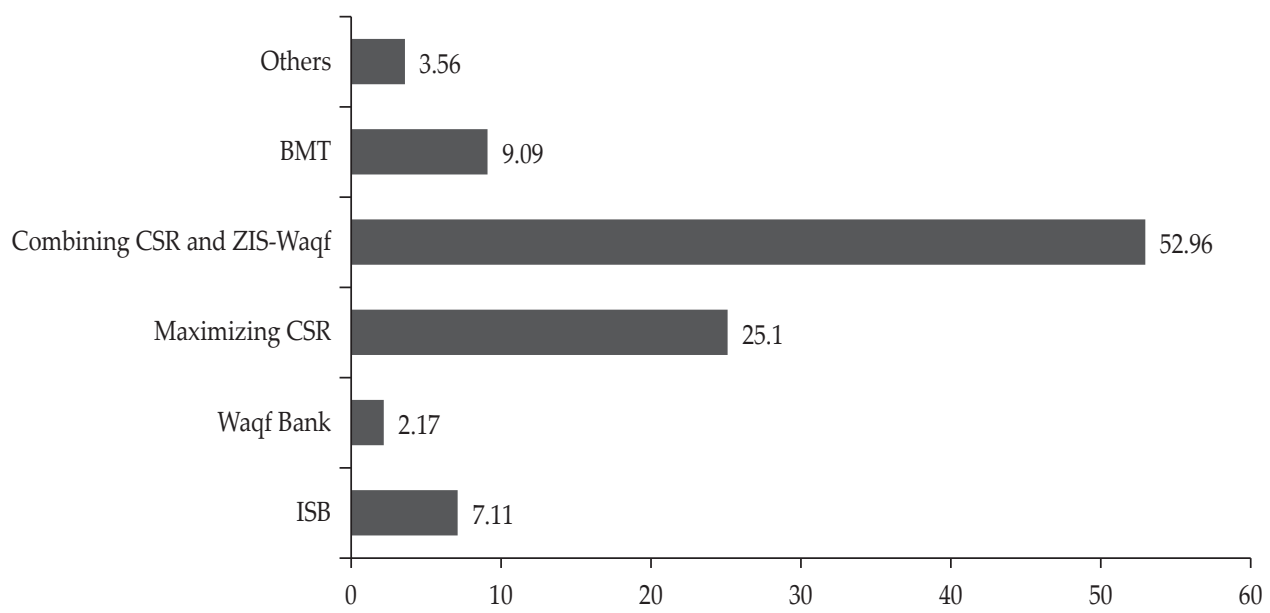

When we scrutinized the first and the second choices, we found that depositors as well as regulators and depositors as well as Sharia advisers were in both positions, not other choices (Graph 4). Supporters for ISB are from depositors only $(3.16 \%)$, depositors as well as borrowers $(1.19 \%)$, depositors as well as practitioners $(1.58 \%)$, a depositor as well as a stockholder $(0.2 \%)$, and community $(0.59 \%)$ (Graph 4). 


\section{Graph 4. Stakeholders' Perception on How to Improve Social Outcomes of IB Based on Their Role (\%)}

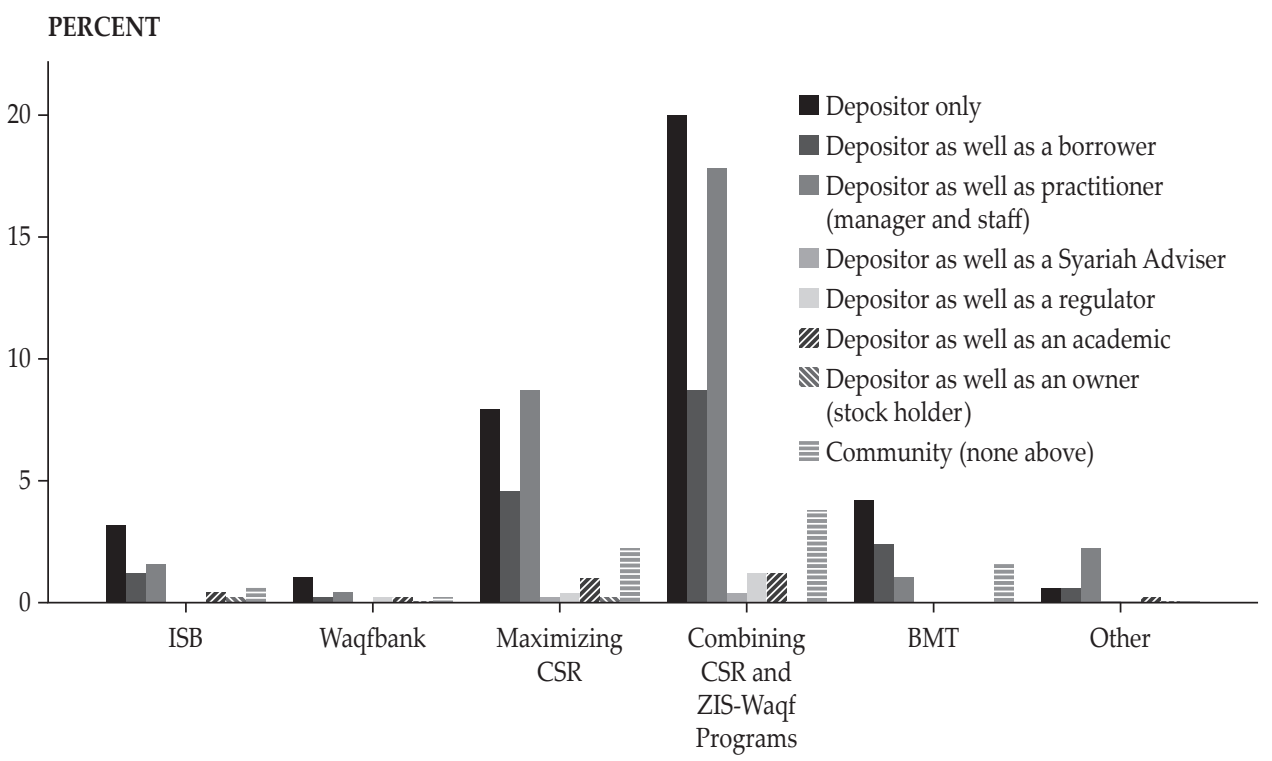

As for the scenarios to improve social responsiveness of IB, experts seemed to have different point of views or even conflicting. For instance, one respondent suggested not to establish a new type of IB since the [Islamic values] of existing banks are not fully implemented. In contrast, the need for establishing a new type of IB to improve their social outcomes could not be negated.

"I don't think it is necessary [to make a new type of bank], because the existing banks are not yet implemented, it may not have the same mindset. If you finally create another banking, worrying doesn't mean anything." R3

"We have learned, we have been in Indonesia for almost more than 25 years, operating in 1992 now in 2017, meaning 25 years. Our market share is still $5.2 \%$ because of the results of the conversion of the BPD Aceh. My question is: if a new bank is created again, do we not repeat the same thing as the existing one?" R10

"This Islamic bank has deviated from its khittah (ideal), now the choice is two: Islamic banks are usually like this, it can be shifted a little but cannot really return to the ideal. Yes, there is a need to establish one more institution that can really combine commercial and social." R1

The respondents who seemed to agree to the idea of establishing a new kind of IB out of the existing one suggested using Baitul Mal wat Tamwil (BMT) or Waqf bank. BMT is a type of Islamic micro finance with two different functions. As its name implies, Baitul Mal refers to treasure house, dedicated for social mission by collecting zakat, infaq, and shadaqah. While Baitut Tamwil (house of wealth management) serves for financial intermediation such as saving and financing (Hadisumarto \& Ismail, 2010). According Aziz (2006) to the initial capital invested in BMT is between IDR20-30 million (around US\$1,333-2,000). Their opinion and their reason are as follows: 
"In my opinion, BMT is more visible because it doesn't need a lot of funds." R1 "There has been a discussion about waqf bank. Waqf banks will maximize existing social funds." R8

Although BMT is attractive to be chosen as an alternative body to enhance social dimension of $\mathrm{IB}$, however, this institution is not without pejorative image. Some suggest avoiding it, as in reality its performance is constantly under questions.

"The role of Baitul Mal of BMT is very limited." R9

"The problem is the Nazir [manager of waqf] and these Muzaki (who pays zakat) are reluctant to go to BMT because BMT has been labeled as a business institution. Even though they distribute their zakat through BMT, the amount is small. Because, BMT's business is small, Muzaki is doubtful. Hence, BMT receives very little funding for the social goals." R5

The majority of respondents suggested combining CSR and the zakat-waqf system, a finding consistent with those in Dusuki (2008) and Raimi et al. (2014). However, while this is theoretically feasible, in practice it may face potentially serious legal challenges.

"Clearly, the character of CSR and waqf is different. The waqf property must be eternal, what we give away is the result of its investment. While CSR runs out, not for endowments. If CSR is combined with waqf, will it be a Nazir activity or bank activity? It must be clear. Because it is something different, if bank activities mean role of Nazir melts, it is gone. If Nazir activities mean that the bank is increasingly lost in its social function, because who have the right to manage and distribute the investment of the waqf are Nazir." R9

Regardless of the aforementioned approaches, from the interviewees' stance, they identified at least other seven policies to improve the social outcomes of IB (Graph 5). Four of them are relating to zakat (Paying zakat, cooperating with BAZNAS, establishing Baitul Mal, and increasing the size of IB). This finding affirms that IB provides more social disclosure than those are not subject to zakat (Maali et al., 2006). First, it is suggested that IB requires to pay zakat, because zakat is one of the main sources of social fund. Second, IB needs to cooperate with BAZNAS (the national zakat amil board) to improve the collection of zakat and its distribution. Third, IB may separately establish Baitul Mal to focus on managing ZIS of within its organization. Fourth, IB needs to constantly increase their sizes, because it will increase the amount of zakat being collected. 


\section{Graph 5. Experts' Views on How to Improve Social Outcomes (Hierarchy Chart Based on Nodes)}

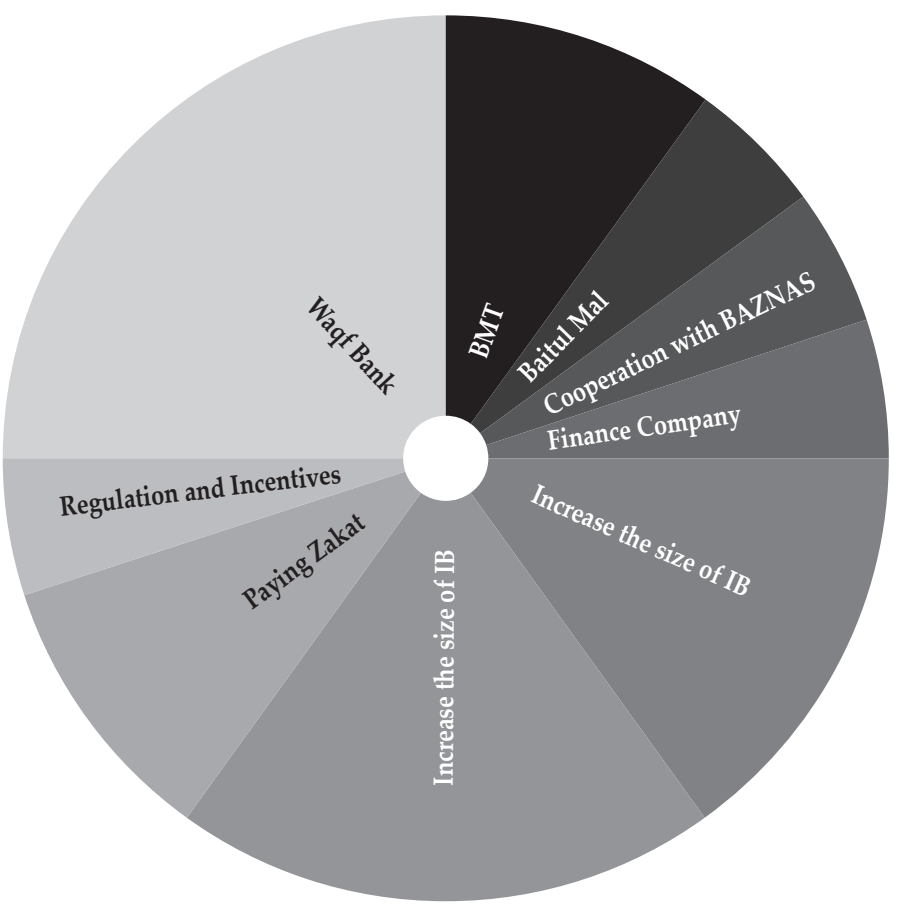

Aside from zakat, two issues need to be settled by regulation body as suggested by the experts. First, the implementation of 3P should be an obligatory rather than an optional choice. This seems important because it constitutes the second largest part of experts' recommendation after establishment of waqf bank. Second, the regulation body should provide incentives to IB in order they easily adopt the policies and gradually shift to implement the policies into practices. Another remaining option is to establish a finance company. It is considered simpler than waqf bank, because it will only manage waqf assets not depositors' money.

\subsection{Responses to Specific Features of ISB}

Although the supporters of ISB were only around 7\% out of 506 respondents; however, it should not be neglected, and it is worth investigating. First, from the expert views, only few recommended ISB as an option, because the existing IB was difficult to be altered.

"Yes, there is a need to establish one more institution that can really combine commercial and social." R1

"ISB should be from waqf, if it uses this channel, then it can be done. We, then, prepare who are the Mauquf 'alaih (beneficiaries of waqf), then distribute it to the beneficiaries." R6 
Second, in the future, most experts followed suitable finance whereby IB should not only focus on its profit or prosperity, but also emphasize on people and planet.

"So it fits perfectly the idea of sustainable finance with IB. Because the bank is a business institution, of course it must be profit, so that from the accounting side it must be sustainable. Then it must also have a good impact on the community, empowering and no exploitation from one party to another. Then the planet must also have a good impact." R4

Table 8.

Stakeholders' Perception on the Characteristics of ISB

\begin{tabular}{llcccc}
\hline & & \multicolumn{2}{c}{ Responses } & Percent of \\
\cline { 1 - 3 } Frequency ISB $^{\text {a }}$ & Banking basic & N & Percent & Cases \\
\cline { 2 - 3 } & Ethical project and preserving environment & 76 & 11.6 & 15.5 \\
& Prioritising local people & 87 & 13.3 & 17.6 \\
& Designing an alternative collateral & 121 & 18.5 & 24.5 \\
& Transparency & 148 & 22.6 & 30.0 \\
& Democratic in decision making & 71 & 10.9 & 14.4 \\
& All applies & 22 & 3.4 & 4.5 \\
& 129 & 19.7 & 26.1 \\
& 654 & 100.0 & $132.4 \%$ \\
\hline
\end{tabular}

a. Dichotomy group tabulated at value 1

Third, the respondents consider that the current IB practice might not allow productive individuals with limited capital to access bank's financing. In contrast, IB supporters seem to overestimate the willingness of Islamic banks to provide long-term financing to support economic growth (Chapra, 1992; Siddiqi, 1983). In this regard, they suggest if a new institution is about to establish, this bank shall design an alternative collateral (22.6\%) (Table 8). This parallels a suggestion by San-Jose et al. (2011) to develop an alternative guarantee system that would be more accessible for small and medium-sized enterprises. Moreover, it should operate locally and aim to serve the lower middle class (18.5\%), which is consistent with Guene and Mayo (2001) and Mohd Nor et al. (2016) and their arguments to provide loans for low-income consumers as well as small and micro enterprises. Furthermore, this hypothesized bank would not only target profitable projects, but also support ethical and environmental projects (13.3\%). The respondents also indicated to some extent that they were in favor of Islamic banks pursuing environmental preservation alongside social banking (Benedikter, 2011; De Clerck, 2009; Weber, 2014). Certainly, while Islamic values consider the environment as having the utmost priority (Abdelzaher, Kotb, \& Helfaya, 2019), in practice it is also somewhat neglected by Islamic banks (Asutay \& Harningtyas, 2015; Haniffa \& Hudaib, 2007).

In addition, as the bank's orientation is lower middle class, then it should focus its service on providing basic savings and financing facilities (11.6\%). This is also in line with proponents of social banking that these banks should pay attention 
to the fulfillment of the basic necessities of life such as consumption, housing, transportation, and communication (Reifner, 1992) .

Expert interviews support all these points. Whether we need establishing a specific institution or improving social outcomes from the existing IB, their ideal features should comprise nine main characteristics (Graph 6), including: (1) transparency, (2) designing an alternative system of collateral, (3) emphasizing green banking and ethical projects, (4) supporting micro enterprises, (5) empowering disadvantaged groups including women and the poor (6) prioritizing the agricultural sector, (7) collecting zakat and cash waqf, (8) creating jobs for people, and (9) using the internet and branchless banking.

\section{Graph 6. Experts' Views on The Features and Characteristics of ISB (Hierarchy Chart Based on Nodes)}

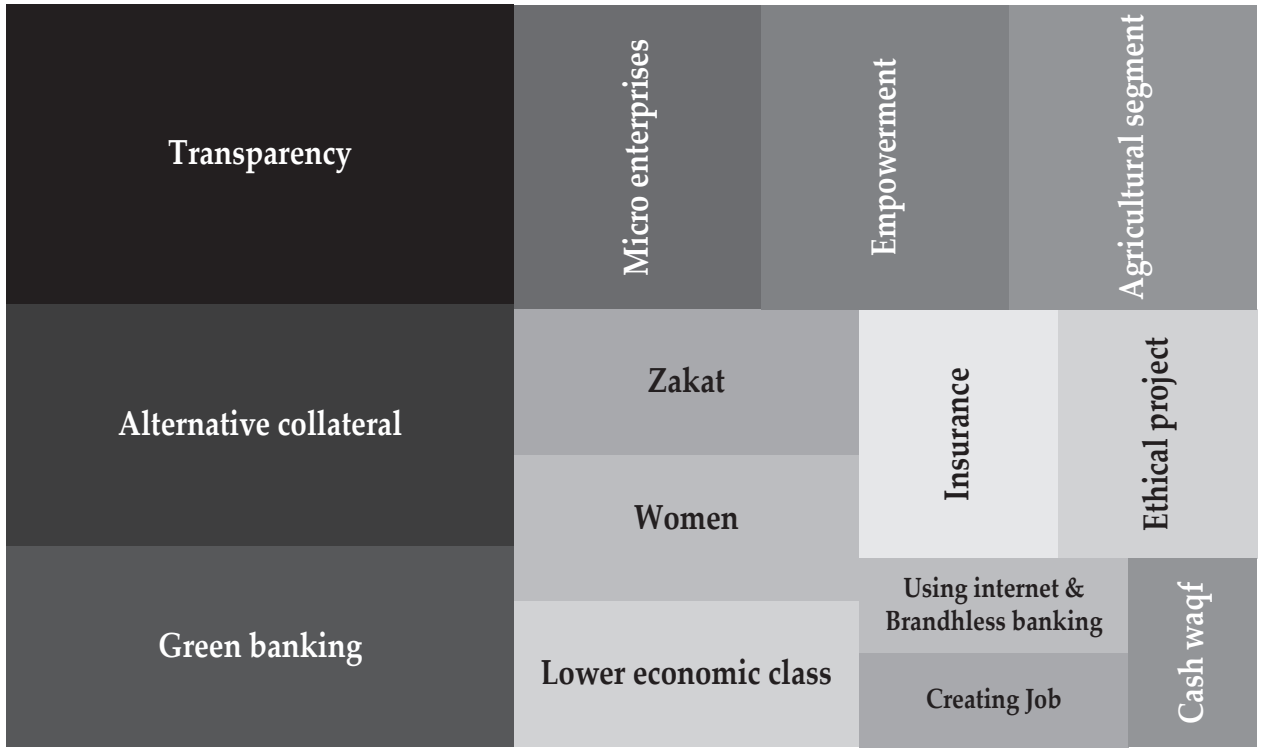

\section{CONCLUSION AND RECOMMENDATION}

\subsection{Conclusion}

This paper has discussed main issues regarding social outcomes and the prospect of establishment of ISB. Employing a survey and interview with some relevant experts and professionals, we highlight important contributions to financial sector, regulation, and policy. First, both survey and interview indicate that the social outcomes of IB are low $(42.89 \%$ the respondents consider IB "admitting responsibility but fight it" or doing the least that is required, while $6.92 \%$ of them suggest IB is "denying responsibility" or doing less than required). Consequently, further improvement should be made. Second, to improve the social responsiveness of IB, the majority of respondents prefer a combination of CSR and the ZIS-Waqf system (52.96\%), or maximizing the role of CSR (25.1\%). Third, although theoretically combining CSR and ZIS-Waqf system is feasible, 
however in the practical sense, it might encounter legal issue as both have different characteristics. Fourth, if ISB is an option, then respondents suggest it should operate in local areas to cater to disadvantaged groups (women and low-income customers). Accordingly, the bank should design an alternative collateral system, more transparent, provides financing to both profitable and ethical projects. The ISB would be advised to target micro enterprises and finance agricultural segment.

\subsection{Recommendation}

We recommend that regulators and practitioners should take actions to improve the social outcomes of IB. We also suggest consideration of establishing an ISB because it helps support the prospects of sustainable finance.

As the respondents suggested, delivering social outcomes may strengthen the reputation of IB. Besides, they also expect that IB should demonstrate social outcomes more than conventional bank. In this regard, we recommend IB practitioners seriously address some of the social matters discussed in this paper that not only relate to the management of zakat and qarh al-hasan, but also to the policy designs that help the underprivileged improve their financial standing. Possibilities include, for instance, extending services to rural areas; designing alternative collateral systems; and promoting or empowering women. While these will incur a cost to a bank, there should be a corresponding gain in reputation. The experience of Bank Tabungan Pembangunan Nasional (BTPN) well illustrates the point, with the bank maintaining both superior financial and social performance after its first financing cycle (BTPNSyariah, 2018).

According to most respondents, the preferred approach to improving social outcomes in IB is through combining CSR and the ZIS-Waqf system. Consequently, regulators could review some of the options for legal reform that would suit this purpose. Further, although only a small number of respondents supported the establishment of an ISB possibly because it is not a well-known alternative banking form in Indonesia, we consider it worthy of attention. We also encourage the regulator to consider the level of obligation involved in sustainable finance given the social contract of IB in Indonesia. In practice, regulators may need to provide some incentives to make this policy more attractive.

Of course, this study has some obvious methodological limitations, including a need to extend the findings in more detail. We recommend that future researchers consider how we could combine CSR and the ZIS-Waqf system as one of the options and whether it would be possible to offer ISB product and services within existing IB banks as an alternative to establishing a separate ISB. 


\section{REFERENCES}

Abdelzaher, D. M., Kotb, A., \& Helfaya, A. (2019). Eco-Islam: Beyond the Principles of Why and What, and Into the Principles of How. Journal of Business Ethics, 155(3), 623-643.

Abdul-Baki, Z., \& Uthman, A. B. (2017). Exploring the "Social Failures" of Islamic Banks: a Historical Dialectics Analysis. Journal of Islamic Accounting and Business Research, 8(3), 250-271.

Abdul-Rahman, A., Latif, R. A., Muda, R., \& Abdullah, M. A. (2014). Failure and Potential of Profit-Loss Sharing Contracts: A Perspective of New Institutional, Economic (NIE) Theory. Pacific-Basin Finance Journal, 28, 136-151.

Ahmad, K. (2000). Islamic Finance and Banking: the challenge and prospects. Review of Islamic economics, 57-82.

Al-Zuhayli, W. (2003). Al-Figh Al-Islami wa Adillatuh (Islamic Jurispudence and Its Proofs) (M. A. El-Gamal, Trans. Vol. 5). Beirut: Dar al-Fikr al-Mouse.

Amaratunga, D., Baldry, D., Sarshar, M., \& Newton, R. (2002). Quantitative and Qualitative Research in the Built Environment: Application of "Mixed" Research Approach. Work study, 51(1), 17-31.

Amran, A., Fauzi, H., Purwanto, Y., Darus, F., Yusoff, H., Zain, M. M., . . Nejati, M. (2017). Social Responsibility Disclosure in Islamic Banks: a Comparative Study of Indonesia and Malaysia. Journal of Financial Reporting and Accounting, 15(1), 99-115.

Asutay, M. (2007). Conceptualisation of the Second Best Solution in Overcoming the Social Failure of Islamic Finance: Examining the Overpowering of Homoislamicus by Homoeconomicus. IIUM Journal in Economics and Management, 15(2), 167-195.

Asutay, M. (2008). Islamic Banking and Finance: Social Failure. New Horizon(No. 169), pp. 1-3. doi:or http://dx.doi.org/10.2139/ssrn.1735674

Asutay, M. (2012). Conceptualising and Locating the Social Failure of Islamic Finance: Aspirations of Islamic Moral Economy vs. The Realities of Islamic Finance. Asian and African Area Studies, 11(2), 93-113.

Asutay, M., \& Harningtyas, A. F. (2015). Developing Maqasid al-Shari'ah Index to Evaluate Social Performance of Islamic Banks: A Conceptual and Empirical Attempt. International Journal of Islamic Economics and Finance Studies, 1(1), 5-64.

Aziz, M. A. (2006). Tata Cara Pendirian BMT. Jakarta: Pusat Komunikasi Ekonomi Syari'ah.

Benedikter, R. (2011). Social Banking and Social Finance: Answers to the Economic Crisis. New York: Springer.

Biswas, D. (2016). A Study of Conceptual Framework on Green Banking. Journal of Commerce and Management Thought, 7(1), 39-53.

Bryman, A. (2016). Social Research Methods. New York: Oxford university press.

BTPNSyariah. (2018). Annual Report 2018: Public. Retrieved February, 222019 https://www.btpnsyariah.com/images/BTPNS_AR_2018_en.pdf

Butzbach, O., \& von Mettenheim, K. E. (2015). Alternative Banking and Theory. Accounting, Economics and Law-A Convivium, 5(2), 105-171.

Carroll, A. B. (1979). A Three-Dimensional Conceptual Model of Corporate Performance. The Academy of Management Review, 4(4), 497-505. doi:10.2307/257850 
Chapra, M. U. (1992). Islam and the Economic Challenge. Hemdon: International Institute of Islamic Thought (IIIT).

Chew, B. C., Tan, L. H., \& Hamid, S. R. (2016). Ethical Banking in Practice: a Closer Look at the Co-operative Bank UK PLC. Qualitative Research in Financial Markets, 8(1), 70-91.

Clarkson, M. E. (1995). A Stakeholder Framework for Analyzing and Evaluating Corporate Social Performance. Academy of management review, 20(1), 92-117.

Colman, A. M., Norris, C. E., \& Preston, C. C. (1997). Comparing Rating Scales of Different Lengths: Equivalence of Scores from 5-point and 7-point Scales. Psychological Reports, 80(2), 355-362.

Cornée, S., \& Szafarz, A. (2014). Vive la Différence: Social Banks and Reciprocity in the Credit Market. Journal of Business Ethics, 125(3), 361-380.

Creswell, J. W. (2009). Research Design: Qualitative, Quantitative, and Mixed Methods Approaches (Third ed.): Sage publications.

De Clerck, F. (2009). Ethical Banking. In Ethical Prospects (pp. 209-227): Springer.

Denzin, N. K., \& Lincoln, Y. S. (2018). The SAGE Handbook of Qualitative Research (Fifth Edition ed.): Sage.

Dusuki, A. W. (2005). Corporate Social Responsibility of Islamic Banks in Malaysia: a Synthesis of Islamic and Stakeholders' Perspectives. (Doctor of Philosophy), Loughborough University, Loughborough. Retrieved from https://dspace. lboro.ac.uk/2134/7725

Dusuki, A. W. (2008). What Does Islam Say about Corporate Social Responsibility. Review of Islamic Economics, 12(1), 5-28.

Elkington, J. (1997). Cannibals with Forks: The Triple Bottom Line of Twentieth Century Business. Capstone: Oxford.

Finstad, K. (2010). Response Interpolation and Scale Sensitivity: Evidence Against 5-Point Scales. Journal of Usability Studies, 5(3), 104-110.

Gait, A., \& Worthington, A. C. (2015). Attitudes of Libyan Retail Consumers toward Islamic Methods of Finance. International journal of Islamic and Middle Eastern finance and management, 8(4), 439-454.

Guene, C., \& Mayo, E. (2001). Banking and Social Cohesion: Alternative Responses to a Global Market: Jon Carpenter Publishing.

Hadisumarto, W. b. M. C., \& Ismail, A. G. B. (2010). Improving the Effectiveness of Islamic Micro-Financing: Learning from BMT Experience. Humanomics, 26(1), 65-75.

Hamidi, M. L., \& Worthington, A. C. (2017). Islamic Banking Plus Social Banking Equals Islamic Social Banking: An Equation in The Making. In K. Jerzy (Ed.), Banking: Services, Opportunities and Risks: Nova Science Publishers, Inc.

Hamidi, M. L., \& Worthington, A. C. (2018). Islamic Social Banking: The Way Forward. Malaysian Journal of Economics, 52(1), 195-207.

Haniffa, R., \& Hudaib, M. (2007). Exploring the Ethical Identity of Islamic Banks via Communication in Annual Reports. Journal of Business Ethics, 76(1), 97-116.

Hassan, M. K., \& Bashir, A.-H. M. (2003). Determinants of Islamic banking profitability. Paper presented at the 10th ERF annual conference, Morocco.

Kamel, S. (1997). Development of Islamic Banking Activity, Problems and Prospects. IDB Prize Winners' Lecture Series(12).

Kamla, R., \& G. Rammal, H. (2013). Social reporting by Islamic Banks: Does Social Justice Matter? Accounting, Auditing \& Accountability Journal, 26(6), 911-945. 
Kaur, G. (2016). Green Initiatives of Banks in India: A Paradigm Shift. Journal of Commerce and Management Thought, 7(3), 488-500.

Korslund, D., \& Spengler, L. (2012). Strong, Straightforward and Sustainable Banking. Global Alliance for Banking on Values, mars.

Kuhn, T. (1996). The Structure of Scientific Revolutions. In. Chicago: University of Chicago Press. (Reprinted from: Reprint Edition).

Kumar, M., Tat Kee, F., \& Taap Manshor, A. (2009). Determining the Relative Importance of Critical Factors in Delivering Service Quality of Banks: an Application of Dominance Analysis in SERVQUAL Model. Managing Service Quality: An International Journal, 19(2), 211-228.

Lewis, M. K., \& Algaoud, L. M. (2001). Islamic Banking. Massachusetts: Islamic Edward Elgar.

Lin, A. C. (1998). Bridging Positivist and Interpretivist Approaches to Qualitative Methods. Policy Studies Journal, 26(1), 162-180.

Maali, B., Casson, P., \& Napier, C. (2006). Social Reporting by Islamic Banks. Abacus, 42(2), 266-289.

Mallin, C., Farag, H., \& Ow-Yong, K. (2014). Corporate Social Responsibility and Financial Performance in Islamic Banks. Journal of Economic Behavior $\mathcal{E}$ Organization, 103, S21-S38.

Mohammad, M. T. S. H. (2011). Towards an Islamic Social (Waqf) Bank. International Journal of Trade, Economics and Finance, 2(5), 381-386.

Mohd Nor, S. (2016). Islamic Social Bank: An Adaptation of Islamic Banking? Jurnal Pengurusan, 46, 43-52.

Mohd Nor, S., Rahim, R. A., \& Senik, Z. C. (2016). The Potentials of Internalising Social Banking among the Malaysian Islamic Banks. Environment, Development and Sustainability, 18(2), 347-372.

Naqvi, S. N. H. (2016). Perspectives on Morality and Human Well-being: A Contribution to Islamic Economics: Kube Publishing Ltd.

Neuman, L. W. (2014). Social Research Methods: Qualitative and Quantitative Approaches (7th ed.). Essex: Pearson Education Limited.

OJK. (2015). Sustainable Finance Roadmap, Facilitating Financial Services Institutions to Innovate. Retrieved from https://www.ojk.go.id/en/berita-dankegiatan/publikasi/Pages/OJK-Sustainable-Finance-Roadmap,-FacilitatingFinancial-Services-Institutions-to-Innovate.aspx

Paulet, E., Parnaudeau, M., \& Relano, F. (2015). Banking with Ethics: Strategic Moves and Structural Changes of the Banking Industry in the Aftermath of the Subprime Mortgage Crisis. Journal of Business Ethics, 131(1), 199-207.

Pikkarainen, K., Pikkarainen, T., Karjaluoto, H., \& Pahnila, S. (2006). The Measurement of End-user Computing Satisfaction of Online Banking Services: Empirical Evidence from Finland. International Journal of bank marketing, 24(3), 158-172.

Poon, W.-C. (2007). Users' Adoption of e-banking Services: the Malaysian Perspective. Journal of Business $\mathcal{E}$ Industrial Marketing, 23(1), 59-69.

Preston, C. C., \& Colman, A. M. (2000). Optimal Number of Response Categories in Rating Scales: Reliability, Validity, Discriminating Power, and Respondent Preferences. Acta psychologica, 104(1), 1-15.

Raimi, L., Patel, A., \& Adelopo, I. (2014). Corporate Social Responsibility, Waqf System and Zakat System as Faith-based Model for Poverty Reduction. World 
Journal of Entrepreneurship, Management and Sustainable Development, 10(3), 228242.

Reifner, U. (1992). Social Banking and New Poverty - Towards a New Approach in Law and Economics. In U. Reifner \& J. Ford (Eds.), Banking for People: SBing and New Poverty Consumer Debts and Unemployment in Europe-National Reports (pp. 23-42). Berlin - New York: Walter de Gruiter.

Roth, W. D., \& Mehta, J. D. (2002). The Rashomon effect: Combining Positivist and Interpretivist Approaches in the Analysis of Contested Events. Sociological Methods E Research, 31(2), 131-173.

Sairally, S. (2007). Community Development Financial Institutions: Lessons in Social Banking for the Islamic Financial Industry. Kyoto Bulletin of Islamic Area Studies, 1(2), 19-37.

San-Jose, L., Retolaza, J. L., \& Gutierrez-Goiria, J. (2011). Are Ethical Banks Different? A Comparative Analysis Using the Radical Affinity Index. Journal of Business Ethics, 100(1), 151-173.

Satkunasegaran, E. (2003). Corporate Governance and the Protection of Customers of Islamic Banks. Paper presented at the Proceedings of the International Islamic Banking Conference.

Schlotzhauer, S. D. (2007). Elementary Statistics Using JMP: SAS Institute.

Shahimi, S., Mohd Marzuki, M., \& Embong, Z. (2013). Potential of Cash Waqf for Poverty Alleviation in Malaysia: A System Dynamics Approach. Jurnal Ekonomi Malaysia, 47(2), 149-163.

Siddiqi, M. N. (1983). Issues in Islamic banking. Leicester: Islamic Foundation.

Siddiqui, S. H. (2001). Islamic Banking: True Modes of Financing. New Horizon, $109,15-20$.

Slaper, T. F., \& Hall, T. J. (2011). The Triple Bottom Line: What is it and How Does It Work. Indiana Business Review, 86(1), 4-8.

Taqi-Usmani, M. (2002). An Introduction to Islamic Finance (Arab and Islamic Laws). In: Boston: CQ.

Tracy, S. J. (2012). Qualitative Research Methods: Collecting Evidence, Crafting Analysis, Communicating Impact: John Wiley \& Sons.

Tripp, C. (2006). Islam and the Moral Economy: The Challenge of Capitalism: Cambridge University Press.

Vanclay, F. (2010). The Triple Bottom Line and Impact Assessment: How Do TBL, EIA, SIA, SEA and EMS Relate to Each Other? In Tools, Techniques And Approaches For Sustainability: Collected Writings in Environmental Assessment Policy and Management (pp. 101-124): World Scientific.

Wartick, S. L., \& Cochran, P. L. (1985). The Evolution of the Corporate Social Performance Model. The Academy of Management Review, 10(4), 758-769. doi: $10.2307 / 258044$

Weber, O. (2014). Social banking: Concept, Definitions and Practice. Global Social Policy, 14(2), 265-267.

Wood, D. J. (1991). Corporate Social Performance Revisited. Academy of Management Review, 16(4), 691-718.

Zakaria, M. (2014). The Influence of Human Needs in the Perspective of Maqasid Al-Syari'ah on Zakat Distribution Effectiveness. Asian Social Science, 10(3), 165175. 